Production

ENGINEERING ARCHIVES
2014, Vol. 5, No 4, pp 26-30

ISSN 2353-5156

ISSN 2353-7779 (print version)

(online version)

Article history: $\quad$ Received: 12.11.2014

Accepted: 28.11.2014

Online: 31.12 .2014

Available online on: http://www.qpij.pl

Exist since $4^{\text {th }}$ quarter 2013

\title{
Supply Selection and Supply Chain Maturity \\ - important areas of the quality production assurance
}

\author{
Ivan Koblen ${ }^{1}, K_{\text {Karol Balog }}^{2}$, Katarína Lestyánszka Škůrková3 \\ ${ }^{1}$ Institute of Safety, Environment and Quality, Faculty of Material Science and Technology in Trnava, Slovak University of Technology in \\ Bratislava, Slovakia, phone: +421 906068502 , e-mails: ivan.koblen@ stuba.sk \\ ${ }^{2}$ Institute of Safety, Environment and Quality, Faculty of Material Science and Technology in Trnava, Slovak University of Technology in \\ Bratislava, Slovakia, phone: +421 906068502 , e-mails: karol.balog@stuba.sk \\ ${ }^{3}$ Institute of Safety, Environment and Quality, Faculty of Material Science and Technology in Trnava, Slovak University of Technology in \\ Bratislava, Slovakia, phone: +421 906068502 , e-mails: katarina.skurkova@stuba.sk
}

\begin{abstract}
The paper pays attention to selected information focused on the key requirements and criteria used in both the conventional supplier selection and sustainable supplier selection processes. The authors introduce the supply chain maturity levels, which, together with the supplier selection and assessment issue, is the essential area for the assurance of the high quality, safety and dependability of the products.
\end{abstract}

Key words - supplier, supply chain, supplier selection, conventional, sustainable, supply chain maturity

\section{Introduction}

Intensive competitive pressure to improve delivery performance and assure product quality, while simultaneously reducing cost, have forced organizations to pay special attention to supplier chain and supply chain management issues. International standard ISO 9001:2008 in Purchasing underlines the necessity of supplier evaluation and selection based on criteria for selection, evaluation and re-evaluation.

In conventional supply chain management, the companies usually evaluate suppliers based on price, quality and delivery time. However, due to environmental, economic and social factors, sustainability has been considered as the most important criteria in the process of supplier selection. The supplier's permanent ability to provide the necessary products (components) and services and meet the customer's requirements is also the principle condition. Taking into account this fact, during the supplier selection and assessment processes companies would also pay appropriate attention to supply chain maturity issue.

\section{Key terms - supplier, supply chain, supply chain management (SCM)}

\section{Supplier}

According to the majority of professional literature the term "supplier" is defined as a person, company, organization (set of organizations) or country, which delivers a product or service (but also finances and information from a source to a customer (SCOTT W., 
Oldied Ch, LAMBeRT D.M., 2008; SimCh-LeVI D., KAMINSKY P., SIMCHI-LEVI E. 2007).

The product or service is delivered to customers (consumers), who have bought and use the products (services).

\section{Supply chain}

Supply chain is a set of organizations directly linked by one or more of the upstream and downstream flows of products, services, finances and information from a source to a customer.(MENTYER,J.T, at.al, 2001) A further, very concise, definition underlines that that Supply Chain is the process through which a company creates and distributes its products and services to the end user. It includes a number of specific elements; production planning, material sourcing, transportation management, warehouse management and demand management. These functions are tightly integrated to provide the products and services to the end user in an efficient, timely and profitable manner.

\section{Supply Chain Management (SCM)}

There is also a lot of definitions of this term. As accepted and useful definitions of Supply Chain Management (SCM) we can introduce the following two definitions:

- Supply chain management is the integration of key business processes across the supply chain for the purpose of creating value for customers and stakeholders (LAMBERT D.M. 2008) Supply chain management is a set of approaches utilized to efficiently integrate suppliers, manufacturers, warehouses and stores, so that merchandise is produced and distributed at the right quantities, to the right locations, and at the right time, in order to minimize systemwide costs while satisfying service level requirement. (Simch LeVi D., KAMINSKY P., SimChI-LEVI E., 2007)

- In general we can note, that SCM is an action based on the integration of organizational units that make up the supply chain and co-ordinating material, information and financial flows in order to meet requirements from the perspective of end users throughout the supply chain and increase the competitiveness of the supply chain.

\section{Supplier selection}

The supplier selection is a principal step from the customer and stakeholders requirements satisfaction point of view. Supplier selection is generally considered as a five-phase process (Fig.1.) starting from the realisation of the need for a new supplier; determination and formulation of decision criteria; prequalification (initial screening and drawing up a shortlist of potential suppliers from a large list); final supplier selection; to the monitoring of the suppliers selected (i.e. continuous evaluation and assessment).

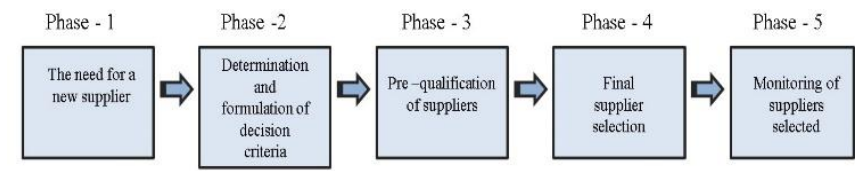

Fig. 1. Phases of supplier selection process.

Source: SONMEZ M.A. 2006

The evaluation and assessment task can proceed in accordance with the following steps:

- identification of decision attributes (criteria) against which the potential suppliers are to be assessed,

- evaluation scales/metrics to measure the appropriateness of a supplier (such metrics or scales are useful and necessary to determine the likely best and worst outcomes for each attribute),

- assignment of weights to attributes to indicate the relative importance and contribution of each criterion to the supplier evaluation and assessment,

- evaluation of potential suppliers against the attributes identified as the beginning using the scales/metrics established.

Evaluation and selection of suppliers is a typical multiple criteria decision making (MCDM) problem involving multiple criteria that can be both qualitative and quantitative. Hence, the supplier selection process requires a formal, systematic and rational selection model.

There are several factors that affect the supplier selection process. Among these factors we can include especially the following primary factors: supplier capacity, type of products, decision criteria, decision makers, sourcing strategy, manufacturing strategies and levels of used technologies, minimum order quantity, delivery time, security aspects during the delivery process, geographic and other preferences. 


\section{Conventional supplier selection}

In conventional supply chain management, the suppliers selection/evaluation are provided on the basis of product/service price, high quality of product, delivery time and level of provided services during and after the product delivery.

The price can be considered as the most important factor in supplier selection and evaluation. In this regard it is very important to pay attention to the product/system life cycle cost, because the buying price composes only the minor part of the total life cycle price. The main part from the whole life cycle cost comprises of the operation and support costs, which can present from $60 \%$ to $80 \%$ of total life cycle cost.

Subsequently, quality has been recognized as the second key criterion in supplier evaluation and selection. The next important criterion in supplier evaluation is delivery time (the ability of the suppliers to satisfy customer requirement in a timely manner as well as responding quickly to the demanded changes). These three criteria - price for delivered products/system, its quality and delivery time - as well as level of provided services have permanently played a dominant role in supplier evaluation and selection.

\section{Sustainable supplier selection}

According to the WCED (World Commission on Environment and Development) definition in 1987, sustainable development means satisfying the present needs without jeopardizing future generation's ability to meet their own requirements and needs. In current literature, however, sustainability is described as having three major dimensions which are environment, society and economy. These dimensions are illustrated in Fig.2, which is called the triple bottom line (TBL) principle. Its core consists in the creation of mutual relations between these dimensions as well as in the achievement of an optimal, balanced relationship between them. This access ensures the sustainable growth of the organization (MOLAMOHAMADI Z., ISMAIL N., LEMAN Z., ZULKIFLI N. 2013).

On a social level, sustainability aims at meeting human needs without violating moral and legal rights. Economic sustainability intends to maximize the in- come flow that could be generated while minimizing the stock of assets. From an environmental perspective, companies' activities should not risk the environment, natural systems and life on Earth.

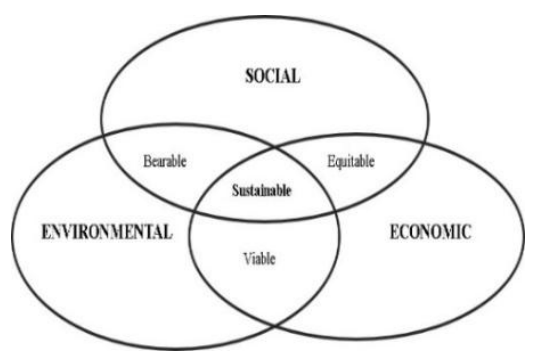

Fig. 2. Three basic pillars of sustainability (triple bottom line /TBL/ principle of companies responsibility) Source: MOLAMOHAMAdI Z., ISMAIL N., .LEMAN Z., ZULKIFLI N., 2013

Fig. 3 illustrates how the relevant supply chain members and stakeholders interact with each other in the context of a sustainable suppler chain. This figure also gives an overview of the sustainable supplier selection process.

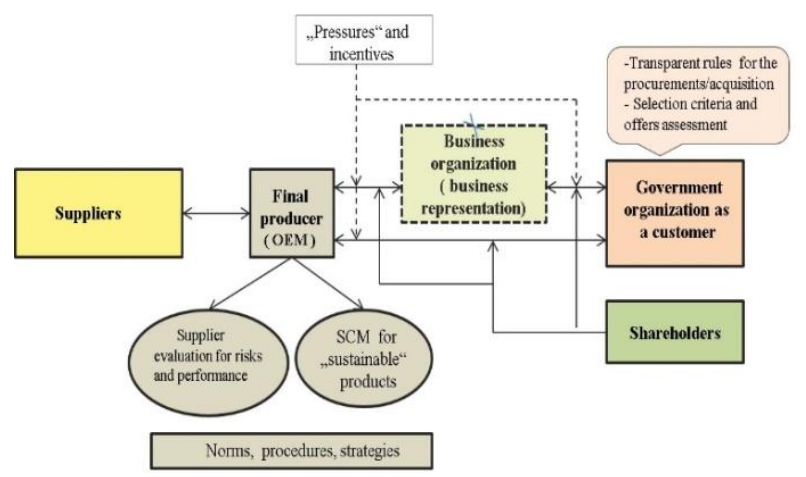

Fig. 3 Participants/stakeholders and sustainable supplier selection process (triggers for sustainable supply chain management)

Source: own elaboration based on Molamohamadi Z., ISMAIL N., LEMAN Z. ,ZULKIFLIN, 2013

In the presented Table 1 the main criteria for sustainable supplier assessment and selection are introduced. These criteria can be divided into four categories: business criteria, economic criteria, social criteria and environmental criteria. In this regard a very important matter for practice is elaboration and implementation of customer strategy focused on responsible supplier management and application of best practices in the suppliers selection. 
Tab.1 Main criteria for sustainable supplier assessment and selection

\begin{tabular}{|c|l|}
\hline $\begin{array}{c}\text { Category of } \\
\text { criteria }\end{array}$ & \multicolumn{1}{|c|}{ Main criteria for sustainable supplier assessment and selection } \\
\hline $\begin{array}{c}\text { Business } \\
\text { criteria }\end{array}$ & $\begin{array}{l}\text { Quality of products and services, ability to meet delivery due dates, industrial knowledge and technical expertise, honest } \\
\text { and frequent communication, commitment to continuous improvement, sharing of information, ability of further product } \\
\text { development (upgrading, modernization), flexibility on contract terms and conditions, supplier process capabilities, } \\
\text { ability to introduce new technologies, safety level of delivered equipment and devices, testing capability, protection of } \\
\text { classified information, preparedness on industrial co-operation, guarantees and insurance, geographical aspects }\end{array}$ \\
\hline $\begin{array}{c}\text { Economic } \\
\text { criteria }\end{array}$ & $\begin{array}{l}\text { Price of product and services (in the product life cycle cost framework), disposal of cost competitive culture, financial } \\
\text { stability and staying power, ability to receive financial sources for production, product delivery and installation }\end{array}$ \\
\hline $\begin{array}{c}\text { Social crite- } \\
\text { ria }\end{array}$ & $\begin{array}{l}\text { Elimination of discrimination in employment (age, religion, gender and other similar factors), child labour, flexible } \\
\text { working arrangements, satisfactory working environment, health and safety of the staff and customers, customer privacy, } \\
\text { cultural properties }\end{array}$ \\
\hline $\begin{array}{c}\text { Environ- } \\
\text { mental crite- } \\
\text { ria }\end{array}$ & $\begin{array}{l}\text { Meeting of legislative conditions focused on environment, environmental management systems for preventing and con- } \\
\text { trolling pollution, resource consumption (energy, water, minerals), recycling, animal rights }\end{array}$ \\
\hline
\end{tabular}

Source: Molamohamadi Z., Ismail N., .Leman Z., Zulkifli N. 2013; Kannan V., TAN K. Ch. 2003; GondéšOvÁ A., GONDÁŠ J., REPA M.

\section{Supply Chain Maturity}

The supply chain maturity is possible to see as a real obtained level of management system development of supplying organizations (NENADÁL J. 2006). In this regard the assurance of the permanent ability to provide the products and services must be considered as a principle condition for accomplishment of all stakeholders requirements. Without the modern and mature management system on the supplier's side it is impossible to expect the high quality, safety and dependability of supplies.
Taking into account this fact world companies and professional organizations in the quality area and supply chain quality have been developing activities and have been using the description of supply chain maturity.

The levels of the supply chain maturity (Table 2) show progress in activities when the supply chain is efficiently managed. Each level contains characteristics associated with factors such as appropriate level of processes management, collaboration, IT integration and others.

Table 2. Supply chain maturity levels

\begin{tabular}{|c|c|c|}
\hline $\begin{array}{c}\text { Maturity } \\
\text { Level }\end{array}$ & Key Characteristics & Typical Company \\
\hline $\begin{array}{l}\text { Controlled } \\
\text { (4th level) }\end{array}$ & $\begin{array}{ll}\text { - } & \text { SCM function is controlled, predictable and managed } \\
\text { - } & \text { Process-oriented SCM functions as opposed to traditional siloed functions } \\
\text { - } & \text { Supply chain becomes a network of collaborators as opposed to competitors } \\
\text { - } & \text { Inter-enterprise IT integration } \\
\text { - } & \text { High degree of trust and dependency } \\
\end{array}$ & - $\quad$ Some global OEMs \\
\hline $\begin{array}{l}\text { Managed } \\
\text { (3rd } \\
\text { Level) }\end{array}$ & $\begin{array}{l}\text { - SCM seen as part of corporate strategy } \\
\text { - Tools and processes exist for cross-firm, cross-functional collaboration } \\
\text { - Very strong intra-corporate IT integration } \\
\text { - Strong supply chain visibility } \\
\text { - } \quad \text { Excellent communication between buyers and suppliers }\end{array}$ & $\begin{array}{ll}- & \text { Tier } 1 \\
- & \text { Progressive Tier } 2 \\
\text { - } & \text { Multi-national organizations } \\
\text { (including maintenance and } \\
\text { repair organizations) }\end{array}$ \\
\hline $\begin{array}{l}\text { Defined } \\
\text { (2nd } \\
\text { Level) }\end{array}$ & $\begin{array}{l}\text { - Moderate internal collaboration across products lines } \\
\text { - } \quad \text { Poderate process structure } \\
\text { - Some IT integration } \\
\text { - SCM is tactical functional }\end{array}$ & $\begin{array}{ll} & \text { Most Tier } 2 \\
\text { - } & \text { Small organizations }\end{array}$ \\
\hline $\begin{array}{l}\text { Ad hoc } \\
\text { (1st level) }\end{array}$ & $\begin{array}{ll} & \text { Limited internal processes } \\
\text { - } & \text { Ad hoc internal collaboration } \\
\text { - } & \text { Limited planning and automation } \\
\text { - } & \text { Inconsistent customer satisfaction }\end{array}$ & - $\quad$ Tier 3 and most SMEs \\
\hline
\end{tabular}

Source: KPMG 2009 


\section{Conclusion}

For an organization, assuring the quality of products, the supplier selection and appropriate knowledge concerning the supply chain maturity can be considered as the first priority in this area. At the present time the supplier selection process needs to cover not only the conventional supplier selection criteria, but also the criteria focused on relevant dimensions of sustainability.

For the near and middle future the supplier selection and capability assessment processes would take into account the following key challenges:

- Improve Flow Management between OEM and suppliers in all stages of the product/system life cycle,

- Develop supplier portfolio by establishing transparent and reliable risk and performance evaluation through shared assessment criterias and early communication of bottlenecks,

- Develop strategic suppliers establishing a high degree of trustworthy collaboration,

- Covering the risk for engineering and design capability, manufacturing (by commodity), supplier's capacity management, planning and financial health, software capability, in-service support ,

- Development of supplier capabilities and proper motivation to improve processes,

- Pay special attention to education, preparation and training of the supply chain management/purchasing staff, because well-trained and open-minded staff in this area are at least as important as strategies and tools. The SCM team and its knowledge in the supplier selection area is crucial for the success of an innovative customer-oriented industry organization.

\section{References}

1. Essig M., TAndler S., Scheckenhofer M. Defence supply\& chain management: Conceptual framework and first empirical findings. http://www.ippa.org/IPPC4/Pro ceedings/03DefenseProcurement/Paper3-3.pdf.

2. GondÁŠOvÁ A., GondÁš J., REPA M. Triple-BottomLine Concept as a tool for achievement of sustainable growth of organization. Slovak. http://emi.mvso.cz/EMI/ 201102/03\%20Gondasova/Gondasova.pdf.
3. ISO 9001:2008. Quality management systems. Requirements.

4. KANNAN V., TAN K.CH. 2003. Attitudes of US and European managers to supplier selection and assessment and implications for business performance. Benchmarking. An International Journal, Vol.10,No.5, http://www.emeraldinsight.com/doi/abs/10.1108/146357 70310495519? journalCode=bij.

5. Koblen I., NižNíKovÁ L. 2013. Selected aspects of the supply chain management in the aerospace industry. INCAS Bulletin. Vol. 5, no. 1, p. 135-149. http://bulletin.incas.ro/volume_5_issue_12013.html.

6. KPMG. 2009. Aerospace Supply Chain Management. http://www.aiac.ca/uploadedFiles/News_and_Events/Cal endar_of_Events/agm/KPMG-EDC_Presn_to_09_AIAC _AGM.pdf.

7. LAMBert D.M. 2008. Supply Chain Management: Processes, Partnership, Performance. $3^{\text {rd }}$ edition.

8. Mentzer T. et.al. 2001. Defining Supply Chain Management. Journal of Business Logistics, Vol.22, No.2.

9. Molamohamadi Z., Ismail N., Leman Z., ZULKIFLi N. 2013. Supplier Selection in a Sustainable Supply Chain. Journal of Advanced Management Science, Vol.1, No.3, September. http://www.joams.com/uploadfile/2013/1023 /20131023054900723.pdf.

10. NenadÁl J. 2006. Partnership Management with Suppliers. New perspective of company purchasing. Management Press, 323pp. Czech.

11. ScotT W., Oldied CH. The Nine Basic Rules of a Successful Supply Chain. http://www.aia-aerospace.org/ assets/smc_wp-nine.pdf.

12. SiMCHI -LEVI L., KAMINSKY O.K., SIMCHI-LEVI E. 2007. Designing and Managing the Supply Chain. $3^{\text {rd }}$ edition, Mcgraw Hill.

13. SonMEZ M. 2006. A Review and Critique of Supplier Selection Process and Practices. Loghborough University, Occasional Paper Series, Paper 2006:1. https://dspace.lboro.ac.uk/dspacespui/handle/2134/2160.

14. UlewicZ R., VASKo A., KlimeCKA-TATAR D. 2014. Controlling of the logistic processes. Production Egineering Archives. Vol. 3(2), p.26-30. 